\title{
PENCEMARAN AIR DAN STRATEGI PENGGULANGANNYA
}

\author{
Oleh : \\ Arie Herlambang \\ Peneliti Pusat Teknologi Lingkungan, BPPT
}

\begin{abstract}
The rapid growth of population in developing country causes environmental contamination by increasing significantly pollution load in river and other water body. It needs efficient and effective strategy to overcome contamination in certain areas. Technical identification of pollution source and its influence to environmental quality is important to should be known and socialized to community. Land use to is important to get priority and should be managed consistently environmentally sound, beside solid waste and domestic wastewater. Law enforcement also should be applied, especially to company or industry which significantly gives contribution to environmental degradation. Environmental restoration need fund, so government as regulator need partner from private to overcome environmental problem. Environmentally based industries and services is needed to be developed as government counterpart, but up to now the development of them retarded caused by non competitive interest of commercial bank. Environmental fund should be collected from polluter through regulated mechanism and In the next future environmental bank should possible manage the fund and finance environmental industry and services to overcome environmental pollution, in this case government act as regulator only.
\end{abstract}

Kata Kunci : Pencemaran air, pengelolaan, sumber daya air, strategi penanggulangan.

\section{PENDAHULUAN}

\subsection{Kondisi Air Dunia dan Indonesia}

Menurut WHO, saat ini terdapat 2 miliar orang yang menyandang risiko menderita penyakit murus disebabkan oleh air dan makanan. Penyakit ini merupakan penyebab utama kematian lebih dari 5 juta anak-anak setiap tahun. Sumber-sumber air semakin dicemari oleh limbah industri yang tidak diolah atau tercemar karena penggunaannya melebihi kapasitasnya untuk dapat diperbaharui. Kalau kita tidak mengadakan perubahan radikal dalam cara kita memanfaatkan air, mungkin saja suatu ketika air tidak lagi dapat digunakan tanpa pengolahan khusus yang biayanya melewati jangkauan sumber daya ekonomi bagi kebanyakan negara (Midleton, 2004).

Sumber kehidupan ini persediaannya terbatas dan semakin hari semakin terpolusi oleh kegiatan manusia sendiri, namun masih terlalu banyak orang yang tidak mempunyai akses ke air. Sekalipun air merupakan sumber daya yang terbatas, konsumsi air telah meningkat dua kali lipat dalam 50 tahun terakhir dan kita gagal mencegah terjadinya penurunan mutu air. Pada saat yang sama, jurang antara tingkat pemakaian air di negara-negara kaya dan negara-negara miskin semakin dalam. Dewasa ini 1,2 milyar penduduk dunia tidak mempunyai akses ke air bersih dan hampir dua kali dari jumlah itu tidak mempunyai fasilitas sanitasi dasar yang memadai.

Portensi dan ketersediaan air di Indonesia saat ini diperkirakan sebesar 15.000 meter kubik perkapita pertahun. Jauh lebih tinggi dari rata-rata pasokan dunia yang hanya 8.000 $\mathrm{m}^{3} / \mathrm{kapita/tahun}$. Pulau Jawa pada tahun 1930 masih mampu memasok $4.700 \mathrm{~m}^{3} / \mathrm{kapita} / \mathrm{tahun}$, saat ini total potensinya sudah tinggal sepertiganya, yakni tinggal $1500 \mathrm{~m}^{3} / \mathrm{kapita} /$ tahun. Pada tahun 2020 total potensinya diperkirakan tinggal $1200 \mathrm{~m}^{3} / \mathrm{kapita} / \mathrm{tahun}$. Dari potensi alami ini, yang layak dikelola secara ekonomi hanya $35 \%$, sehingga potensi nyata tinggal 400 $\mathrm{m}^{3} / \mathrm{kapita/tahun,} \mathrm{jauh} \mathrm{dibawah} \mathrm{angka} \mathrm{minimum}$ PBB, yaitu sebesar $1.000 \mathrm{~m}^{3} / \mathrm{kapita} /$ tahun. Padahal dari jumlah $35 \%$ tersebut, sebesar $6 \%$ diperlukan untuk penyelamatan saluran dan sungai-sungai, sebagai maintenance low.

Oleh karena itu pada tahun 2025, Internasional Water Institute, menyebut Jawa dan beberapa pulau lainnya termasuk dalam wilayah krisis air. Berdasarkan studi Water Resources Development (1990), tahun 1990 Pulau Jawa sudah mengalami defisit air, dari kebutuhan 66.336 juta $\mathrm{m}^{3} /$ tahun hanya bisa disediakan 43.952 juta $\mathrm{m}^{3} /$ tahun. Joko Pitono (2003) juga mengkaji bahwa pada musim kemarau tahun 1993, 75\% Pulau Jawa sudah mengalami kekeringan akibat defisit air dan diperkirakan 
defisit air akan meningkat pada tahun 2000 menjadi 56\%, suatu angka yang mengkhawatirkan dan perlu diwaspadai secermat mungkin.

Kantor Menteri Negara Lingkungan Hidup tahun 1997, dalam neraca airnya menyatakan bahwa secara nasional belum terjadi defisit air, tetapi khusus untuk Jawa, Bali sudah terjadi defisit tahun 2000 dan tahun 2015 bertambah dengan wilayah Sulawesi dan NTT.

\subsection{Sifat Air dan Karakter Air Limbah}

\subsubsection{Sifat Air}

Air yang secara kimia, hanya terdiri dari atom $\mathrm{H}$ dan $\mathrm{O}$ mempunyai sifat yang unik. Tanpa air tidak akan mungkin terdapat kehidupan. Air di alam dijumpai dalam tiga bentuk, yakni bentuk padat sebagai es, bentuk cair sebagai air, dan bentuk gas sebagai uap. Bentuk mana yang akan ditemui, tergantung keadaan cuaca setempat. Kepadatan (density), seperti halnya bentuk, juga tergantung pada temperatur dan tekanan barometris $(P)$.

Pada umumnya densitas meningkat dengan menurunnya temperatur, sampai tercapai maksimum pada $4^{\circ} \mathrm{C}$ Celsius, apabila temperatur turun lagi, maka densitas akan turun pula. Sekalipun demikian temperatur air tidaklah mudah berubah. Hal ini nampak dari spesifik heat air, yakni angka yang menunjukkan jumlah kalori yang diperlukan untuk menaikkan suhu satu gram air satu derajat celsius. Spesifik heat air adalah $1 / \mathrm{gram} /{ }^{\circ} \mathrm{C}$, suatu angka yang sangat tinggi dibandingkan spesifik heat elemen-elemen lain di alam. Dengan demikian tranfer panas dari dan kedalam air tidak banyak menimbulkan perubahan temperatur.

Kapasitas panas yang besar ini juga menyebabkan efek stabilitas badan air terhadap udara sekitarnya. Kondisi ini sangat penting untuk melindungi kehidupan akuatik yang sangat sensitif terhadap gejolak suhu. Pada tekanan atmosfir air mendidih pada $100{ }^{\circ} \mathrm{C}$, karena tekanan di daerah tinggi lebih rendah dari satu atmosfir, maka air mendidih pada temperatur yang lebih rendah.

\subsubsection{Karakterisrik Air Limbah}

Secara awam air tercemar dapat dilihat dengan mudah, misalnya dari kekeruhan, karena umumnya orang berpendapat bahwa air murni atau bersih itu jernih dan tidak keruh, atau dari warnanya yang transparan dan tembus cahaya, atau dari baunya yang menyengat hidung, atau menimbulkan gatal-gatal pada kulit dan ada juga yang dapat merasakan dengan lidah, seperti rasa asam dan getir. Dengan demikian, sebenarnya mudah untuk mengenal pencemaran, oleh karena itu jangan meremehkan informasi dan keluhan masyarakat tentang pencemaran air. Air tercemar juga dapat diketahui dari matinya atau terganggunya organisme perairan, baik ikan, tanaman dan hewan-hewan yang berhubungan dengan air tersebut. Dalam menentukan karakteristik limbah, parameter-parameter yang dipakai antara lain :

1) Parameter Suhu. Parameter ini sangat diperlukan dalam penentuan karakter limbah, karena menyangkut kecepatan reaksi dan pengaruhnya terhadap kelarutan suatu gas, bau dan rasa. Beberapa jenis bakteri populasinya dipengaruhi oleh suhu dari limbah, dan organisme perairan sangat peka terhadap perubahan suhu air. Pengukuran suhu dapat dipakai termometer khusus yang dapat dipakai untuk setiap variasi kedalaman.

2) Parameter Rasa dan Bau. Parameter ini seringkali diakibatkan oleh materialmaterial terlarut, dapat berupa zat organik seperti phenol dan Khlorophenol. Bau dan Rasa merupakan sifat air yang sangat subyektif, karena itu sulit diukur, tetapi bisa di identifikasi seperti bau busuk, bau gas, rasa pahit, dan rasa masam.

3) Parameter Warna. Estetika air sering dilihat dari warna. Air yang jernih, transparan, segar dan tidak bau merupakan indikator air bagus secara awam. Namun demikian penting untuk dapat membedakan antara air yang mempunyai warna asli akibat material terlarut dan warna semu akibat zat-zat yang tersuspensi. Warna kuning alami pada air yang berasal dari daerah pegunungan adalah berasal dari asamasam organik yang tidak berbahaya bagi kesehatan, dan warna ini bisa disamakan dengan warna asam tanik yang terdapat dalam air teh. Namun demikian banyak konsumen atau pemakai air yang menolak air dengan warna yang terlalu menyolok atas dasar alasan estetika. Demikian pula dengan industri tertentu, air berwarna sering kali tidak dapat diterima, misalnya pada industri kertas yang bermutu tinggi.

4) Parameter Kekeruhan. Hadirnya material berupa koloid menyebabkan air menjadi tampak keruh yang secara estetis kurang menarik dan mungkin bisa berbahaya bagi kesehatan. Kekeruhan dapat pula disebabkan oleh partikelpartikel tanah liat, lempung, lanau atau akibat buangan limbah rumah tangga 
maupun limbah industri atau bahkan karena adanya mikroorganisme dengan jumlah besar.

5) Parameter Padatan. Padatan hadir dalam air berupa zat-zat tersuspensi atau terlarut dan dapat dibedakan dalam bentuk organik atau inorganik. Total Padatan Terlarut (Total Dissolved Solid TDS) adalah jumlah padatan yang berasal dari material-material terlarut, sedangkan Padatan Tersuspensi (Suspended Solid=SS) adalah partikel tersuspensi yang dapat diukur dengan menggunakan kertas saring halus. Padatan yang dapat diendapkan (Settleable Solid) adalah jumlah padatan yang dapat dipisahkan dari air dengan prosedur standard, yaitu perbedaan antara SS dalam supernatan dan SS dalam sampel air. Pengukuran Settleable Solid biasanya menggunakan kerucut Imhoff berukuran satu liter.

6) Parameter Kondutivitas. Konduktivitas suatu larutan tergantung pada jumlah garam-garam terlarut dan untuk larutan yang encer konduktivitasnya kurang lebih akan sebanding dengan nilai TDS. Secara matematis $\mathrm{K}=$ (Konduktivitas $\mu \mathrm{mhos} / \mathrm{m}) /($ TDS - $\mathrm{mg} / \mathrm{l})$. Dengan mengetahui nilai $\mathrm{K}$ untuk suatu sampel air tertentu, pengukuran konduktivitas air dapat dipakai untuk memperkirakan jumlah TDS secara cepat dan mudah.

7) Parameter pH. Tingkat asiditas atau alkalinitas suatu sampel diukur berdasarkan skala $\mathrm{pH}$ yang dapat menunjukkan konsentrasi ion hidrogen dalam larutan tersebut. Skala $\mathrm{pH}$ mempunyai rentang $0-14$, dengan nilai 7 sebagai $\mathrm{pH}$ netral, di bawah 7 larutan disebut asam sedangkan di atas 7 larutan disebut basa. Reaksi kimia banyak dikendalikan oleh nilai $\mathrm{pH}$ dan demikian pula aktivitas biologi yang biasanya dibatasi oleh rentang $\mathrm{pH}$ yang sangat sempit $(\mathrm{pH}$ antara $6-8)$. Air yang terlalu asam atau basa tidak dikehendaki oleh karena akan bersifat korosif atau kemungkinan akan sulit diolah.

8) Parameter Oxidation Reduction Potential(ORP). Dalam setiap sistem yang sedang melangsungkan proses oksidasi, akan terjadi perubahan yang terus menerus rasio antara material dalam bentuk tereduksi dan material yang teroksidasi. Dalam situasi semacam itu, potensial yang diperlukan untuk mentranfer elektron-elektron dari oksidator ke reduktor dinyatakan sebagai
ORP. Pengalaman-pengalaman operasional suatu sistem menunjukkan bahwa nilai ORP dapat dijadikan indikator kritis bagi beberapa reaksi oksidasi. Misalnya reaksi dalam proses aerobik menunjukkan nilai ORP lebih besar dari $200 \mathrm{mv}$, sedangkan reaksi anaerobik terjadi pada nilai ORP dibawah $50 \mathrm{mv}$.

9) Parameter Alkalinitas. Alkalinitas disebabkan oleh hadirnya bikarbonat $\left(\mathrm{HCO}_{3}\right)$, karbonat $\left(\mathrm{CO}_{3}^{-}\right)$, atau hidroksida $\left(\mathrm{OH}^{-}\right)$, maka air dikatakan mempunyai alkalinitas. Pada umumnya alkalinitas disebabkan oleh bikarbonat yang berasal dari larutnya batu kapur dalam air tanah. Alkalinitas sangat berguna dalam air maupun air limbah, karena dapat memberikan buffer untuk menahan perubahan $\mathrm{pH}$.

10) Parameter Asiditas. Air alam dan air limbah rumah tangga umumnya mempunyai buffer dalam bentuk sistem $\mathrm{CO}_{2}-\mathrm{HCO}_{3}$, asam karbonat, $\mathrm{H}_{2} \mathrm{CO}_{3}$ tidak bisa dinetralkan secara sempurna sampai pada $\mathrm{pH}$ 8,2 dan tidak akan menahan perubahan $\mathrm{pH}$ dibawah 4,5 , sehingga asiditas $\mathrm{CO}_{2}$ akan terjadi rentang $\mathrm{pH}$ antara $8,2-4,5$, sedangkan asiditas dari mineral (hampir semuanya akibat dari limbah industri) terjadi dibawah 4,5, seperti alkalinitas, asiditas juga dinyatakan dalam mg/l $\mathrm{CaCO}_{3}$.

11) Parameter Kesadahan. Kesadahan adalah sifat air yang dapat mencegah pembentukan busa dalam pemakaian sabun dan dapat menimbulkan kerak dalam peralatan-peralatan yang berhubungan dengan pemakaian air panas. Kesadahan terutama disebabkan oleh ion-ion $\mathrm{Ca}^{++}$dan $\mathrm{Mg}^{++}$, walaupun sebenarnya $\mathrm{Fe}^{++}$dan $\mathrm{Cr}^{++}$juga menimbulkan kesadahan. Hadirnya kesadahan biasanya dikaitkan dengan $\mathrm{HCO}_{3}{ }^{-}, \mathrm{SO}_{4}{ }^{2-}, \mathrm{Cl}^{-}$, dan $\mathrm{NO}_{3}{ }^{-}$. Kesadahan tidak membahayakan kesehatan, namun sangat merugikan, yaitu dapat mengakibatkan pemborosan dalam pemakaian sabun dan pemakaian bahan bakar pemanas air serta kerusakan peralatan yang menggunakan air panas. Kesadahan dinyatakan dengan satuan $\mathrm{mg} / \mathrm{l} \mathrm{CaCO}_{3}$ dan dibagi dalam dua macam, yaitu kesadahan karbonat (metal dengan $\mathrm{HCO}_{3}{ }^{-}$) dan Kesadahan non karbonat (metal dengan $\mathrm{SO}_{4}{ }^{2-}, \mathrm{Cl}^{-}$, dan $\mathrm{NO}_{3}{ }^{-}$.

12) Parameter Oksigen Terlarut. Oksigen adalah elemen yang paling penting dalam pengendalian kualitas air. 
Hadirnya oksigen dalam air sangat penting bagi kelangsungan hidup makluk biologi tingkat tinggi dan dampak pembuangan air limbah ke sungai atau badan air akan ditentukan oleh kesetimbangan oksigen dalam sistem tersebut. Hanya saja oksigen mempunyai daya larut yang rendah dalam air, misalnya pada suhu $0,10,20$, dan $30^{\circ} \mathrm{C}$ adalah masing-masing 14,$6 ; 11,3 ; 9,1$; dan $7,6 \mathrm{mg} / \mathrm{l}$. Air permukaan yang mengalir deras dan jernih, biasanya mengandung oksigen dengan kadar yang jenuh, akan tetapi oksigen yang terlarut tersebut dapat berkurang secara cepat akibat hadirnya air limbah yang banyak mengandung bahan organik. Ikan-ikan besar bisa tahan hidup pada konsentrasi hidrogen paling sedikit 5 $\mathrm{mg} / \mathrm{l}$, sedangkan ikan-ikan tertentu masih bisa hidup pada kondisi oksigen terlarut $2 \mathrm{mg} / \mathrm{l}$. Air yang banyak mengandung oksigen rasanya segar dan untuk meningkatkan oksigen terlarut biasanya dilakukan aerasi. Namun demikian untuk pemakaian tertentu, misalnya ketel uap, oksigen terlarut tidak dikehendaki sebab dapat meningkatkan resiko berkaratnya peralatan.

13) Parameter Kebutuhan Oksigen. Senyawa-senyawa organik pada umumnya tidak stabil dan mungkin saja teroksidasi secara biologis atau kimiawi menjadi bentuk yang lebih sederhana atau stabil. Indikator adanya zat organik dalam air limbah dapat diperoleh dengan cara mengukur jumlah kebutuhan oksigen yang diperlukan untuk menstabilkannya dan dapat dinyatakan dengan parameter BOD, Angka Permanganat, atau COD.

14) Parameter Nitrogen. Nitrogen merupakan elemen penting, karena reaksi biologi dapat berlangsung hanya jika tersedia nitrogen yang cukup. Nitrogen hadir di alam dalam 4 senyawa pokok : 1). Nitrogen-Organik, yaitu nitrogen yang berupa protein asam amino dan urea; 2). Nitrogen Amonia, yaitu nitrogen dalam bentuk senyawa garam amonium, misalnya : $\left(\mathrm{NH}_{4}\right)_{2} \mathrm{CO}_{3}$, atau sebagai amonia bebas; 3 ). Nitrogen Nitrit, yaitu nitrogen dalam bentuk nitrit yang merupakan hasil oksidasi sementara (akan segera berubah menjadi nitrat) dan pada umumnya ditemukan dengan konsentrasi rendah; dan 4). Nitrogen Nitrat, yaitu merupakan hasil oksidasi akhir dari nitrogen. Konsentrasi nitrogen untuk masing- masing bentuk senyawanya yang saling berhubungan dapat memberikan petunjuk yang berguna terhadap sifatsifat dan daya cemar suatu sampel air atau limbah cair. Sebelum dilakukan analisis bakteriologi, kualitas air seringkali diperkirakan atas dasar nitrogennya. Air yang mengandung nitrogen organik dan nitrogen amonia dengan konsentrasi tinggi serta $\mathrm{NO}_{2}-\mathrm{N}$ dan $\mathrm{NO}_{3}-\mathrm{N}$ dengan konsentrasi rendah akan dianggap berbahaya (tidak aman), karena keadaan demikian menunjukkan bahwa pencemaran akan atau sedang berlangsung. Di lain pihak, suatu sampel yang tidak lagi terdapat nitrogen organik dan amonia atau yang mengandung sedikit $\mathrm{NO}_{3}-\mathrm{N}$ akan dianggap aman, sebab proses nitrifikasi telah terjadi yang berarti pencemaran tidak berlangsung lagi.

15) Parameter Khlorida. Khlorida adalah penyebab rasa payau dalam air dan merupakan indikator pencemaran dari air limbah rumah tangga, mengingat khlorida berasal dari urine manusia. Batas rasa asin untuk $\mathrm{Cl}^{-}$ini adalah 250 - $500 \mathrm{mg} / \mathrm{l}$, walaupun sampai $1500 \mathrm{mg} / \mathrm{l}$ sebenarnya belum membahayakan kesehatan manusia.

16) Parameter Biologi. Hampir semua air limbah mengandung beraneka ragam mikroorganisme, misalnya air limbah rumah tangga dapat mengandung lebih dari $10^{6}$ individu/ml, tetapi angka yang tepat seringkali tidak dapat diukur. Setelah mengalami pengolahan limbah konvensional, efluen masih mengandung bermacam-macam mikroorganisme dengan jumlah yang cukup tinggi. Pada pengolahan limbah sistem biologi, mikroorganisme dijaga dan dipelihara untuk proses degradasi limbah dengan waktu tinggal tertentu. Dalam pelaksanaannya, untuk mengenal bau dan warna, walaupun ada peralatannya, kita dapat mengenal secara visual, sedangkan kemasaman atau total padatan terlarut atau total padatan tersuspensi diperlukan metode pengukuran yang lebih akurat dengan peralatan yang sudah baku. Dalam menentukan air tercemar diperlukan pembanding, sebagai rona awal ketika belum diadakan kegiatan. Parameter yang umum dipakai untuk mengenal adanya pencemaran adalah BOD dan COD. BOD (Biological Oxigen Demand) adalah banyaknya oksigen yang dibutuhkan oleh bakteri untuk 
menguraikan bahan pencemar dalam kondisi baku. Sedangkan COD (Chemical Oxigen Demand) mencerminkan kebutuhan bahan kimia yang dibutuhkan untuk mengoksidasi bahan pencemar yang ada dalam air. Oleh karena itu nilai BOD dan COD yang tinggi menunjukkan air tercemat berat. Pada limbah-limbah yang mudah terurai secara biologi, perbandingan BOD dan COD tidak besar $(1-1,5)$, tetapi untuk yang sulit terurai secara biologi perbandingannya dapat menjadi sangat tinggi $(2,5$ - 5). Radio BOD/COD menentukan proses pengolahan yang direncanakan dan waktu tinggal limbah dalam reaktor, yang langsung berpengaruh terhadap volume kontruksi dan luas lahan yang dibutuhkan oleh unit pengolahan limbah.

\section{PENCEMARAN AIR}

\subsection{Definisi}

Dalam UU No 23 Tahun 1997 tentang Pengelolaan Lingkungan Hidup dan PP RI No 82 Tahun 2001 tentang Pengelolaan Kualitas Air dan Pengendalian Pencemaran Air yang dimaksud dengan Pencemaran Air adalah masuknya atau dimasukkannya makluk hidup, zat, energi dan atau komponen lain ke dalam air oleh kegiatan manusia, sehingga kualitas air turun sampai ke tingkat tertentu yang menyebabkan air tidak dapat berfungsi sesuai dengan peruntukkannya. Dari definisi tersebut tersirat bahwa pencemaran air dapat terjadi secara sengaja maupun tidak sengaja dari kegiatan manusia pada suatu perairan yang peruntukkannya sudah jelas. Bagaimana dengan badan air yang peruntukannya belum jelas? apakah pelaku dapat dituduh sebagai pencemar ?

\subsection{Air Bersih dan Limbah Cair Perkotaan.}

Sumber air didayagunakan menusia untuk berbagai keperluan. Pendayagunaan air dalam berbagai bidang budaya, antara lain untuk transportasi, menghasilkan listrik dari energi potensial pada bendungan, industri dan pariwisata. Perkembangan budaya ini terjadi akibat peningkatan kebutuhan yang dirasakan manusia dan adanya interaksi manusia itu sendiri dengan lingkungan air. Peninggalan sejarah telah menunjukkan bahwa air telah memberi rangsangan bagi perkembangan budaya manusia purba, tampak pada benda-benda purbakala yang seringkali terdapat pada penggalian berupa periuk-periuk yang dipakai untuk menyimpan air. Perlengkapan sanitasi sudah ada sejak jaman Neolithic (2000 BC), berupa latrine (kakus) dan saluran drainase, ditemukan dalam masyarakat Minoan di Pulau Crete, Yunani. Pada jaman Romawi juga sudah ditemukan terowongan air besar, sepanjang 80 $\mathrm{km}$, yang membawa air bersih dari pegunungan masuk ke dalam kota dan adanya saluran buangan dari kakus ke luar kota. Pada tahun 1579 di Inggris, khususnya di kota London sudah ada kebijakan yang mengatur untuk setiap 60 rumah di suatu jalan disediakan 3 buah kakus umum (sistem komunal). Adanya kebijakan ini menunjukkan bahwa pada masa itu limbah domestik sudah menjadi masalah bagi masyarakat kota London. Pada tahun 1815 di Inggris sudah ada Undang-Undang yang melarang pembuangan air limbah ke saluran air hujan, karena pada akhirnya air hujan akan masuk ke sungai dan sungai merupakan sumber air bersih bagi masyarakat. Namun demikian dalam rangka memperbaiki keadaan, pada Tahun 1847 diberlakukan Undang-Undang yang mewajibkan warga London untuk membuang limbah dari kakus ke saluran air buangan. Namun air buangan dialirkan ke Sungai Thames, padahal sungai Thames dipergunakan sebagai sumber air minum. Setelah beberapa lama saluran pembuangan bocor dan akuifer air tanah tercemar dan Sungai Thames menjadi tidak nyaman untuk dipandang, bau dan menjadi sumber penyakit. Selang 7 Tahun dari kebijakan tersebut, tepatnya tahun 1854 , terjadilah wabah kolera di Broad Street yang menewaskan 10.000 orang. Sejak saat itu orang mulai sadar adanya hubungan antara limbah pada air minum dan penyakit, seperti kolera dan tipus. Air dan Budaya hidup nampaknya tidak banyak berubah, walaupun sudah ratusan tahun. Kondisi saat ini tidak jauh berbeda, sungai-sungai di kota besar, seperti Jakarta, Semarang, dan Surabaya mempunyai kecenderungan untuk tercemar dengan limbah dari domestik, industri dan pertanian. Pencemaran air di Jakarta telah menunjukkan gejala yang cukup serius, terutama yang berasal dari buangan industri dari pabrikpabrik yang membuang begitu saja air limbahnya tanpa pengolahan lebih dahulu ke sungai atau ke laut, dan tidak kalah memegang andil baik secara sengaja atau tidak adalah masyarakat Jakarta itu sendiri, yakni akibat air buangan rumah tangga yang jumlahnya makin hari makin besar sesuai dengan perkembangan penduduk maupun perkembangan kota Jakarta. Kondisi tersebut diperburuk lagi dengan rendahnya kesadaran sebagian masyarakat yang membuang kotoran maupun sampah ke dalam sungai, dengan demikian akan mempercepat pencemaran sungai-sungai yang ada di Jakarta. Padatnya pemukiman dan kondisi sanitasi lingkungan yang buruk, serta buangan industri yang langsung 
dibuang ke badan air tanpa proses pengolahan telah menyebabkan pencemaran sungai-sungai yang ada di Jakarta, dan air tanah dangkal di sebagian besar daerah di wilayah DKI Jakarta, bahkan kualitas air di perairan teluk Jakartapun sudah menjadi semakin buruk dari tahun ke tahun.

Air limbah kota-kota besar di Indonesia khususnya Jakarta secara garis besar dapat dibagi menjadi tiga yaitu air limbah industri dan air limbah domistik yakni yang berasal dari buangan rumah tangga, dan yang ke tiga yakni air limbah dari perkantoran dan pertokoan (daerah komersial). Saat ini selain pencemaran akibat limbah industri, pencemaran akibat limbah domistikpun telah menunjukkan tingkat yang cukup serius. Di Jakarta misalnya, sebagai akibat masih minimnya fasilitas pengolahan air buangan kota, mengakibatkan tercemarnya badan - badan sungai oleh air limbah domestik, bahkan badan sungai yang diperuntukkan sebagai bahan baku air minumpun telah tercemar pula. Dari hasil penelitian yang dilakukan oleh Dinas Pekerjaan Umum (PU) DKI Jakarta bersama-sama dengan Tim JICA (1989), Besarnya buangan air limbah dari rumah tangga per orang per hari adalah 118 liter, dengan konsentrasi BOD rata-rata 236 $\mathrm{mg} / \mathrm{lt}$ dan pada tahun 2010 nanti diperkirakan akan meningkat menjadi 147 liter dengan konsetrasi BOD rata-rata $224 \mathrm{mg} / \mathrm{lt}$.

Jumlah air buangan secara keseluruhan di

DKI Jakarta diperkirakan sebesar 1.316.113 $\mathrm{m}^{3} /$ hari, yakni air buangan domestik 1.038.205 $\mathrm{m}^{3} /$ hari, buangan perkantoran dan daerah komersial $448.933 \mathrm{~m}^{3} /$ hari dan buangan industri $105.437 \mathrm{~m}^{3} /$ hari. Untuk wilayah Jakarta, dilihat dari segi jumlah, air limbah domistik (rumah tangga) memberikan kontribusi terhadap pencemaran air sekitar $75 \%$, air limbah perkantoran dan daerah komersial $15 \%$, dan air limbah industri hanya sekitar $10 \%$. Sedangkan dilihat dari beban polutan organiknya, air limbah rumah tangga sekitar $70 \%$, air limbah perkantoran $14 \%$, dan air limbah industri memberikan kontribusi $16 \%$. Dengan demikan air limbah rumah tangga dan air limbah perkantoran adalah penyumbang yang terbesar terhadap pencemaran air di wilayah DKI Jakarta. Masalah pencemaran oleh air limbah rumah tangga di wilayah DKI Jakarta lebih diperburuk lagi akibat berkembangnya lokasi pemukiman di daerah penyangga yang ada di sekitar Jakarta, tanpa dilengkapi dengan fasilitas pengolahan air limbah, sehingga seluruh air limbah dibuang ke saluran umum dan akhirnya mengalir ke badanbadan sungai yang ada di wilayah DKI Jakarta.

llustrasi mengenai pemakaian air dan nasibnya sebagai limbah cair tersebut memberi gambaran bahwa air merupakan sumberdaya yang harus dikelola secara hati-hati, mengingat pertumbuhan penduduk dan pengembangan industri selalu diikuti dengan peningkatan kebutuhan air bersih, bersamaan dengan itu terjadi pula peningkatan jumlah air limbah yang dibuang ke perairan, karena sebagian besar dari bersih yang dipakai akan dibuang ke perairan kembali sebagai limbah.

\section{PENYAKIT DAN AIR}

Beberapa penyakit yang berhubungan dengan air (Waterborne Deseases) telah dikenal sejak lama. Pencemaran air minum oleh air limbah dan/atau oleh kotoran manusia (tinja), yang mengandung organisme yang dapat menimbulkan penyakit, virus, bakteria patogen dan sebagainya, dapat menyebar dengan cepat ke seluruh sistem jaringan pelayanan air minum tersebut, serta dapat menyebabkan wabah atau peledakan jumlah penderita penyakit di suatu wilayah dalam waktu singkat.

Beberapa ciri khusus penyebaran penyakit-penyakit tersebut antara lain yakni proses penularan umumnya melalui mulut; terjadi di daerah pelayanan yang airnya tercemar; penderita umumnya terkonsentrasi pada suatu wilayah secara temporer; penderitanya tidak terbatas pada suku, umur, atau jenis kelamin tertentu; meskipun sulit mendeteksi bakteri patogen dalam air, tetapi dapat di perkirakan melalui pemerikasaan/pendeteksian bakteri coli yang disebabkan oleh pencemaran tinja; dan waktu inkubasi biasanya sedikit lebih panjang dibandingkan apabila keracunan oleh makanan. Beberapa penyakit yang paling sering berjangkit antara lain yakni:

\subsection{Disentri}

Penyebabnya adalah beberapa jenis bakteri dysentery baccilus, waktu inkubasi 1 - 7 hari, biasanya sekitar 4 hari atau kurang. Gejala penyakitnya antara lain : bakteri dysentery yang masuk melalui mulut akan tumbuh di dalam perut besar, dan berubah secara lokal ke kondisi sakit misalnya timbulnya bisul pada selapur lendir (mucous membrane). Gejala utama yakni mencret, mulas, demam, rasa mual, muntahmuntah, serta berak darah campur lendir. Infeksi penyakit ini dapat berjangkit sepanjang tahun. Penderita dan carriernya adalah sumber penuranan yang utama, dan penularannya dapat terjadi melalui makanan, air minum atau kontak orang ke orang.

\subsection{Tipus dan Paratifus}

Penyebabnya adalah jenis bacillus typhus dan parathyphus, dengan waktu inkubasi antara 1 sampai 3 minggu. Bakteri penyakit tersebut 
masuk melalui mulut dan menjangki pada struktur lympha (getah bening) pada bagian bawah usus halus, kemudian masuk ke aliran darah dan akan terbawa ke organ-organ internal sehingga gejala muncul pada seluruh tubuh misalnya: seluruh badan lemas, pusing, hilang nafsu makan, dan timbul deman serta badan menggigil. Pada penderita yang serius sering timbul gejala pendarahan usus. Suhu badan berfluktuasi dan akan turun perlahan-lahan setelah infeksi berjalan tiga atau empat minggu, dan gejala umum juga hilang. Untuk penyakit paratyphus, gejalanya hampir sama, hanya lebih lunak. Sumber penularan yang utama adalah penderita itu sendiri atau carriernya, dan penularan dapat terjadi karena infeksi yang disebabkan oleh bakteria yang ada di dalam tinja penderita melalui air minum, makanan atau kontak langsung.

\subsection{Kholera}

Penyebabnya adalah bakteri patogen jenis vibrio cholerae, dan waktu inkubasinya antara beberapa jam sampai lima hari. Bakteri vibrio cholerae yang masuk melalui mulut akan berkembang di dalam usus halus (small intestine), dan menghasilkan exotoxin yang menyebabkan rasa mual. Gejala yang penting yakni mencret atau diare dengan warna putih keruh dan muntah-muntah. Kadang-kadang juga terjadi dehidrasi, dan pada kasus yang serius kemungkin an dapat menyebabkan penderita menjadi koma. Keadaan kritis tersebut dapat dihindari apabila dilakukan penanganan yang sesuai. Sumber utama penunularan yakni air minum atau makanan yang terkontaminasi atau tercemar oleh kotoran atau muntahan penderita ataupun tercemar oleh inang atau pembawa bakteri kholera.

\subsection{Hepatitis A}

Penyebabnya adalah virus hepatitis $A$, dengan waktu inkubasi antara 15 sampai 30 hari (biasanya 30 hari). Infeksi umumnya terjadi melalui mulut. Gejala primairnya antara lain rasa mual, pusing disertai demam, dan rasa lelah/lemas di seluruh tubuh. Gelaja spesifik antara lain terjadinya pembengkaan liver dan timbul gejala sakit kuning. Sumber penularan yakni air minum atau makanan yang tercemar oleh kotoran manusia yang mengandung virus hepatitis $A$.

\subsection{Poliomelistis Anterior Akut}

Penyebabnya adalah virus polio, waktu inkubasi antara 3 sampai 21 hari, biasanya antara 7 sampai 12 hari. Virus polio masuk melalui mulut dan menginfeksi seluruh struktur tubuh, kemudian menjalar melalui simpul saraf lokal, dan selanjutnya menyerang sistem saraf pusat, yang dapat menyebabkan kelumpuhan. Beberapa gejala dapat terlihat antara yakni demam, rasa meriang/tak enak badan, tenggorokan sakit, pusing-pusing dan terjadi kejang mulut (bibir atas dan bawah tidak dapat digerakkan). Sumber infeksi yakni virus polio yang terdapat pada tinja atau dahak penderita atau virus yang terbawa oleh inangnya (carrier), dan penularan kadang-kadang juga melalui air minum atau makanan yang terkontaminasi (tercemar).

\section{PENYAKIT DAN ZAT KIMIA DALAM AIR}

Resiko atau bahaya terhadap kesehatan dapat juga akibat adanya kandungan zat atau senyawa kimia dalam air minum, yang melebihi ambang batas konsentarsi yang diijinkan. Adanya zat/senyawa kimia dalam air minum ini dapat terjadi secara alami dan atau akibat kegiatan manusia misalnya oleh limbah rumah tangga, industri dll. Beberapa zat /senyawa kimia yang bersifat racun terhadap tubuh manusia misalnya logam berat, pestisida, senyawa mikro polutan hidrokarbon, zat-zat radio aktif alami atau buatan dan sebagainya. Beberapa contoh senyawa kimia racun yang sering ada dalam air minum antara lain yakni :

\subsection{Nitrat}

Salah satu contoh sumber pencemaran nitrat terhadap air minum yakni akibat kegiatan pertanian. Meskipun pencemaran nitrat juga dapat terjadi secara alami, tetapi yang paling sering yakni akibat pencemaran yang berasal dari air limbah pertanian yang banyak mengandung senyawa nitrat akibat pemakaian pupuk nitrogen (urea). Senyawa nitrat dalam air minum dalam jumlah yang besar dapat menyebabkan methaemoglobinameia, yakni kondisi dimana haemoglobin di dalam darah berubah menjadi methaemoglobin sehingga darah menjadi kekurangan oksigen. Hal ini dapat mengakibatkan pengaruh yang fatal, serta dapat mengakibatkan kematian khususnya pada bayi.

\subsection{Fluorida}

Fluorida adalah senyawa kimia yang secara alami ada dalam air pada berbagai konsentrasi. Pada konsentrasi yang lebih kecil $1,5 \mathrm{mg} / \mathrm{l}$, sangat bermanfaat bagi kesehatan khususnya kesehatan gigi, karena dapat mencegah kerusakan gigi. Tetapi pada konsentrasi yang besar (lebih besar $2 \mathrm{mg} / \mathrm{l}$ ), dapat menyebabkan kerusakan gigi (fluorosis) yakni gigi menjadi bercak-bercak. Pemaparan fluorida pada konsentrasi yang lebih besar lagi (3 
- 6 mg/l), dapat menyebabkan kerusakan pada struktur tulang. Oleh kerana itu, dosis fluorida dalam air minum dibatasi maksimal $0,8 \mathrm{mg} / \mathrm{l}$.

\subsection{Air Raksa (Merkuri, $\mathrm{Hg}$ )}

Air raksa atau mercury adalah unsur logam yang termasuk logam berat yang bersifat racun terhadap tubuh manusia. Bisanya secara alami ada dalam air dengan konsentrasi yang sangat kecil. Pencemaran air atau sumber air oleh merkuri umumnya akibat limbah limbah yang berasal dari industri. Pada tahun 1950an, kasus pencemaran oleh logam berar khusunya merkuri telah terjadi di teluk Minamata, Jepang, dan telah meracuni penduduk di daerah sekitar teluk Minamata tersebut. Logam merkuri atau air raksa $(\mathrm{Hg})$ ini dapat terakumulasi di dalam produk perikanan atau tanaman dan jika produk tersebut dimakan oleh manusia akan dapat terakumulasi di dalam tubuh. Akumulasi logam $\mathrm{Hg}$ ini dapat meracuni tubuh dan mengakibatkan kerusakan permanen terhadap sistem saraf, dengan gejala sakit-sakit pada seluruh tubuh. Oleh karena itu, di Jepang, penyakit karena kercunan merkuri $(\mathrm{Hg})$ dinamakan penyakit Itai-itai yang berarti sakitsakit, atau sering disebut juga dengan penyakit Minamata (Minamata disease). Dari hasil peneletian, kasus penyakit di Minamata tersebut disebabkan karena pencemaran air oleh limbah yang mengandung merkuri khlorida $(\mathrm{HgCl})$ yang dikeluarkan oleh pabrik-pabrik di sekitar teluk Minamata.

\subsection{Kadmium}

Konsentrasi kadmium (Cd) dalam air olahan (finished water) yang dipasok oleh PAM umumnya sangat rendah, karena umumnya senyawa alami senyawa kadmium ini jarang terdapat di dalam sumber air baku, atau jika ada konsentrasinya di dalam air baku sangat rendah. Selain itu dengan pengolahan air minum secara konvesional, senyawa kadmium ini dapat dihilangkan dengan efektif. Air minum biasanya mengandung kadmium (Cd) dengan konsentrasi $1 \mathrm{~g}$, atau kadang-kadang mencapai $5 \mathrm{~g}$ dan jarang yang melebihi $10 \mathrm{~g}$. Pada beberapa wilayah tertentu yang struktur tanahnya banyak mengandung kadmium, air tanahnya kadang juga mengandung kadmium dengan konsentrasi agak tinggi. Konsentrasi kadmium dalam air minum yang cukup tinggi, kemungkinan juga dapat terjadi pada wilayah yang dipasok dengan air dengan $\mathrm{pH}$ yang sedikit asam. Hal ini disebabkan karena pada $\mathrm{pH}$ yang agak asam bersifat korosif terhadap sistem plumbing atau bahan sambungan perpipaan yang mengandung kadmium. Tingkat konsentrasi kadmium ini merupakan fungsi berapa lama air kontak/berhubungan dengan sistem perpipaan (plumbing system), dan sebagai akibatnya apabila dilakukan pemeriksaan contoh pada lokasi yang sama, seringkali terdapat variasi tingkat konsentrasi. Oleh karena itu untuk mendapatkan konsentrasi rata-rata yang akurat, memerlukan data yang cukup banyak. Keracunan oleh kadmium menunjukkan gejala yang mirip dengan gejala penyakit akibat keracunan senyawa merkuri $(\mathrm{Hg})$ atau penyakit Minamata. Berdasarkan baku mutu air minum yang dikeluarkan oleh WHO (1971), kadar kadmium maksimum dalam air minum yang dibolehkan yakni 0,01 mg/l, sedangkan menurut Peraruran Pemerintah Republik Indonesia No: 20 Tahun 1990, kadar maksimum kadmium dalam air minum yang dibolehkan yakni 0,005 mg/l.

\subsection{Selenium}

Selenium dalam air dengan konsentrasi yang agak tinggi biasanya terdapat di daerah seleniferous. Di daerah seperti ini kandungan selinium dalam air tanah (sumur) ataupun air permukaan dapat mencapai orde $\mathrm{mg} / \mathrm{l}$. Berdasarkan penelitian terhadap tikus betina, LD50 akut melalui mulut untuk sodium selenate yakni $31,5 \mathrm{mg} / \mathrm{kg}$ berat tubuh, dan berdasarkan pengetesan toksisitas akut terhadap tikus, menunjukkan penurunan gerakan spontan, pernafasan yang cepat dan hebat, diare dan selanjutnya mati karena susah bernafas. Gejala subakut meliputi menurunnya laju pertumbuhan, terjadi hambatan terhadap intake makanan, dan keluarnya cairan kotoran (tinja). Berdasarkan hasil penelitian terhadap tikus dengan memberikan dosis secara kontinyu selama satu bulan melalui mulut, gejala toksisitas subakut dari sodium selenate terjadi pada dosis 1 $\mathrm{mg} / \mathrm{kg} / \mathrm{hari}$ untuk tikus jantan dan $5 \mathrm{mg} / \mathrm{kg} /$ hari untuk tikus betina. Setelah pemberian dosis terus-menerus selama satu bulan, terjadi anemia yang disebabkan menurunya jumlah sel darah merah serta jumlah haemoglobin, dan berdasarkan hasil pembedahan terjadi akumulasi sodium selenate pada hati, ginjal, testis, paruparu dan limpha. Bedasarkan penelitian toksisitas baik akut maupun subakut dari selenium tersebut maka WHO menetapkan kadar maksimun selenium yang dibolehkan dalam air minum yakni 0,01 mg/l, dan menurut Peraruran Pemerintah Republik Indonesia No: 20 Tahun 1990, kadar maksimum selenium dalam air minum yang dibolehkan juga 0,01 mg/l.

\subsection{Trihalomethan}

Saat ini beberapa salah satu masalah yang banyak dijumpai dalam air minum yakni masalah yang termasuk polutan mikro yang 
terjadi akibat hasil samping proses khlorinasi. Senyawa tersebut antara lain yakni trihalomethan atau disingkat THMs. Trihalomethane adalah senyawa organik derivat methan $\left(\mathrm{CH}_{4}\right)$ yang mana tiga buah atom Hidrogen $(\mathrm{H})$ nya diganti oleh atom halogen yakni khlor $(\mathrm{Cl})$, Brom $(\mathrm{Br})$, lodium (I). Beberapa senyawa trialomethane yang umum dijumpai antara lain yakni khloroform $\left(\mathrm{CHCl}_{3}\right)$, dibromokhloromethan $\left(\mathrm{CHBr}_{2} \mathrm{Cl}\right)$, bromoform (CHBr3). Jumlah total ke empat senyawa tersebut sering disebut total trihalomethan (TTHM). Selain ke empat senyawa tersebut di atas masih ada beberapa senyawa trihalomenthan lainnya tetapi biasanya kurang stabil. Adanya senyawa trihalomethan dalam air minum ini pertama kali diungkapkan oleh J. Rook pada sekitar tahun 1972. Pada tahun 1975 Rook mempresentasikan secara lebih lengkap hasil penelitiannya tentang beberapa faktor yang menyebabkan terbentuknya senyawa THMs dalam air minum. Rook menyatakan bahwa senyawa THMs terbentuk akibat reaksi antara senyawa khlorine dengan senyawa alami seperti senyawa humus yang ada dalam air baku. Setelah penemuan Rook tersebut, Environmental Protection Agency (EPA) Amerika Serikat mempresentasikan hasil penelitian yang dilakukan oleh "National Organic Reconnaissance Survey (NORS) yang menyatakan bahwa THMs ditemukan hampir di seluruh air miunm (finished water) dan hanya kadang-kadang saja ditemukan pada air bakunya. Pada tahun 1976, National Cancer Institute mengumumkan bahwa senyawa khloroform yang merupakan senyawa senyawa THMs yang sering dijumpai dalam air minum, dengan dosis yang cukup tinggi dapat menyebabkan kanker pada tikus. Sekarang ini, hampir tidak ada keraguan lagi bahwa senyawa THMs khususnya khloroform adalah senyawa yang sangat potensial dapat menyebabkan kanker. Oleh karena itu, konsentrasi senyawa THMs dalam air maksimum yang dibolehkan umumnya yakni 0,01 mg/l, bahkan ada beberapa standar menetapkan konsentrasi maksimum THMs dalam air minum lebih kecil dari yang tersebut diatas.

\section{PENYAKIT DAN KEBERSIHAN}

\subsection{Cara Masuk Penyakit}

Diare atau sering disebut "buang-buang air" adalah penyakit yang erat kaitannya dengan kebersihan. Penyakit ini adalah salah satu penyakit yang paling banyak terjadi di negara berkembang, termasuk di Indonesia. Yang paling banyak terserang penyakit ini umumnya adalah anak-anak balita, dan bila keadaannya parah seringkali dapat menyebabkan dehidarasi, yang apabila tidak ditangani dengan segera dapat pula menyebabkan kematian. Bakteri patogen yang menyebabkan penyakit ini berasal dari tinja, dan masuk ke tubuh manusia lewat mulut melalui makanan atau minuman atau melalui kontak orang ke orang. atau secara langsung melalui inangnya misalnya oleh lalat.

\subsection{Pencegahan}

Sering kali organisme penyebab infeksi enterik tersebut diakibatkan oleh kondisi lingkungan rumah yang kotor dan tidak sehat. Hal tersebut juga sering diakibatkan oleh pencucian tangan yang kurang bersih pada waktu buang kotoran. Salah satu faktor adalah perlunya peningkatan ketersediaan air bersih dalam sarana sanitasi. Akhir-ahkir ini mulai banyak dijual tisu basah atau dalam bentuk cairan, yang mengandung disinfektan dan mulai banyak digunakan dalam kalangan terbatas. Penyakit bisa juga terjadi akibat makanan atau minuman yang dijual oleh penjaja atau warungwarung yang kebersihannya kurang memandai. Salah satu cara yang paling sederhana untuk mencegahnya adalah menghindarinya.

Kebersihan lingkungan dapat meningkatkan kesehatan masyarakat. Salah satu upaya untuk meningkatkan kebersihan lingkungan adalah peningkatan pelayanan air bersih, disamping itu perlu diupayakan perbaikan pada sistem pembuangan limbah atau pengolahan kotoran manusia (tinja), serta dengan memberikan pengetahuan kepada masyarakat tentang pentingnya kebersihan lingkungan atau lebih luas lagi mengenai kesehatan lingkungan.

\section{STRATEGI PENANGULANGAN}

\subsection{Pengaturan Tata Ruang}

Tata Ruang memegang peranan penting dalam pengelolaan lingkungan. Tata Ruang yang baik mengatur pemanfatan ruang dengan mempertimbangkan beban lingkungan yang akan muncul jika ruangnya sudah terpakai. Tata Ruang yang berwawasan lingkungan akan menghasilkan model-model kota atau desa yang akrab dengan lingkungan atau yang sekarang dikenal dengan "eco city". Untuk kota lama yang sudah terbangun memang sulit untuk menatanya kembali, namun demikian bukanlah tidak mungkin untuk dilakukan. Dengan bantuan penegakan hukum dan pembinaan yang terus menerus serta sosialisasi yang baik hal itu bisa dilakukan.

\subsection{Aspek Legal : Pembinaan Dan Penegakan Hukum}


Pemerintah berperan sangat penting, terutama dalam penegakan Undang-Undang, Peraturan Pemerintah, Peraturan Daerah, Keputusan Gubernur atau Bupati. Peraturan lingkungan banyak berubah dan bertambah dari tahun ke tahun, oleh karena itu perlu terus dilakukan sosialisasi baik secara langsung maupun tidak langsung kepada masyarakat. Pelanggaran lingkungan banyak terjadi karena sebagian masyarakat belum membaca atau memahami peraturan-peraturan yang ada, mengingat isu lingkungan masih relatif baru buat Indonesia dan penegakan hukumnya masih sangat minim dibanding kasus-kasus lain.

Penegakan peraturan harus diikuti pula oleh monitoring yang handal untuk mendukung data-data pencemaran. Pembuktian kasus pencemaran merupakan salah satu kelemahan yang sering terjadi dan kondisi ini mempersulit dalam penegakan hukum lingkungan di Indonesia. Oleh karena itu diperlukan laboratorium lingkungan yang independen dan terakriditasi dan mempunyai sertifikasi secara internasional guna mendukung penegakan hukum.

Dalam rangka pengelolaan kualitas air dan pengendalian pencemaran air dipergunakan Peraturan Pemerintah Nomor 82 Tahun 2001. Dalam pasal 8, PP No 82 Tahun 2001 dikenal kriteria mutu air berdasarkan kelas, dimana klasifikasinya adalah sebagai berikut :

- Kelas satu, air yang peruntukannya dapat digunakan untuk air baku air minum, dan atau peruntukan lain yang mempersyaratkan mutu air yang sama dengan kegunaan tersebut;

- Kelas dua, air yang peruntukannya dapat digunakan untuk prasarana / sarana rekreasi air, pembudidayaan ikan air tawar, peternakan ,air untuk mengairi pertamanan, dan atau peruntukkan lain yang mempersyaratkan mutu air yang sama dengan kegunaan tersebut;

- Kelas tiga, air yang peruntukannya dapat digunakan untuk pembudidayaan ikan air tawar, peternakan, air untuk mengairi pertamanan, dan atau peruntukan lain yang mempersyaratkan air yang sama dengan kegunaan tersebut;

- Kelas empat, air yang peruntukannya dapat digunakan untuk mengairi, pertamanan dan atau peruntukan lain yang mempersyaratkan mutu air yang sama dengan kegunaan tersebut.

Peraturan Pemerintah Nomor 82 Tahun 2001 merupakan perubahan dari Peraturan Pemerintah Nomor 20 Tahun 1990. Pada PP.
No. 82 tahun 2001 ini sudah tidak terdapat lagi kelas air yang siap dapat diminum, seperti Golongan A pada PP. No. 20 tahun 1990. Kelas terbaiknya adalah air yang peruntukkannya digunakan sebagai air baku air minum (Lampiran 1). Dengan adanya Pada PP. No. 82 tahun 2001, sebaiknya diikuti oleh pengkelasan badan air. Dengan demikian bagi Industri atau Pemukiman yang membuang limbah di badan air tersebut akan mempertimbangkan kelas peruntukkan badan air. Titik kritis perhatian terletak pada badan air yang termasuk dalam kelas satu. Dalam kondisi seperti itu apakah mungkin baku mutu air dapat berbeda dari yang ditetapkan oleh Kepmen No. 51/MENLH/10/1995 ?. Dengan Adanya otonomi daerah, pemerintah daerah sangat memungkinkan untuk mengeluarkan Perda yang aturannya lebih ketat dari Kepmen No. 51/MENLH/10/1995, dengan demikian sumber air baku untuk minumnya dapat terlindungi.

\subsection{Baku Mutu}

Peraturan Pemerintah Nomor 82 Tahun 2001 adalah merupakan standard badan air (stream standard), sedangkan standard buangan mengacu pada standard baku mutu. Untuk baku mutu buangan tergantung kepada jenis kegiatannya, sebagai contoh :

1) Baku mutu limbah cair bagi Kegiatan Industri diatur oleh KEPMEN LH Nomor 51/MENLH/10/1995; dalam Kepmen ini industri yang diatur: 1). Soda/klor, 2). Pelapisan logam, 3). Penyamakan kulit, 4). Minyak sawit, 5). Pulp dan kertas, 6). Karet, 7). Gula, 8). Tapioka, 9). Tekstil, 10). Pupuk urea, 11). Ethanol, 12). Monosodium glutamat, 13). Kayu lapis, 14). Susu dan makanan yang terbuat dari susu, 15). Minuman ringan, 16). Sabun, deterjen dan produk minyak nabati, 17). Bir, 18). Baterei sel kering, 19). Cat, 20). Farmasi dan 21). Pestisida.

2) Baku mutu limbah cair bagi kegiatan hotel diatur oleh KEPMEN LH Nomor 52/MENLH/10/1995;

3) Baku mutu limbah cair bagi kegiatan rumah sakit diatur oleh KEPMEN LH Nomor 58/MENLH/12/1995; dan

4) Baku mutu limbah cair bagi kegiatan minyak dan gas serta panas bumi diatur oleh KEPMEN LH Nomor 42/MENLH/10/1996.

Sudah menjadi rahasia umum, walaupun lebih dari $75 \%$ pencemaran pada sungai-sungai besar berasal dari limbah domestik, seperti pemukiman dan perkantoran, namun demikian 
mengenai baku mutu limbah domestik belum diatur secara khusus. Namun demikian baku mutu yang lebih mendekati untuk limbah domestik adalah baku mutu limbah hotel, yang diatur dalam KEPMEN LH Nomor 52/MENLH/10/1995.

\subsection{Perlindungan Sumber Air}

Perlindungan sumber air meliputi perlindungan daerah resapan air dengan cara pembatasan bangunan, pelarangan penebangan hutan dan pembukaan hutan, penguasaan sumber-sumber air oleh individu atau pengambilan yang berlebihan, perlindungan dari pencemaran baik oleh domestik maupun oleh Industri. Sebagai langkah pencegahan sumber air perlu dilindungi dari pencemaran, oleh karena itu bagi Industri yang terletak di daerah hulu, harus dikenai peraturan lingkungan yang lebih ketat dibandingkan yang terletak di hilir, karena jika mereka membuang limbah ke sungai atau perairan sekitar, maka air tersebut akan mengalir ke daerah hilir dan banyak dimanfaatkan oleh masyarakat dan jika terjadi pencemaran dampaknya akan sangat luas. Dalam rangka perlindungan Sumberdaya Air ini telah telah dikeluarkan Undang-undang Nomor 7 tahun 2004 tentang Sumber Daya Air, sebagai pengganti Undang-undang Nomor 11 tahun 1974 tentang pengairan. yang dianggap sudah tidak sesuai dengan tuntutan perkembangan keadaan, dan perubahan dalam kehidupan masyarakat. Dalam Undang-undang Nomor 7 tahun 2004 telah diatur mengenai perlindungan sumberdaya air.

\subsection{Monitoring dan Evaluasi}

Data perupakan penunjang yang sangat penting dalam mengevaluasi kondisi lingkungan dan penegakan hukum lingkungan. Untuk menghindari adanya perdebatan yang berkepanjangan tentang permasalahan lingkungan diperlukan pusat data. Untuk pengisian data diperlukan monitoring, terutama perairan-perairan yang dianggap rawan atau daerah industri yang diduga mencemari. Mengingat luasnya kegiatan dan besarnya biaya yang dikeluarkan untuk monitoring, maka tidak setiap daerah dapat dimonitor kualitas air secara rutin. Dalam kondisi normal monitoring yang tidak rutin tidak menimbulkan masalah, tetapi mungkin situasi tersebut dimanfaatkan oleh industri yang nakal untuk membuang limbahnya disaat lengah. Akibatnya sasaran kegiatan untuk perbaikan lingkungan tidak pernah tercapai.

Penegakan hukum tidak dapat dilakukan dengan tegas tanpa didukung data pendukung hasil monitoring yang akurat dan kontinu. Data hasil monitoring juga harus diolah dalam database yang bagus dan format yang baku, mengingat demikian banyaknya permasalahan lingkungan yang ada membutuhkan kecepatan dalam proses pencarian berkas dan proses pembaharuan atau penambahan data. Dengan berkembangnya teknologi, proses monitoring dapat dilakukan secara on line atau langsung, terutama pada wilayah atau daerah yang dianggap kritis dan perlu pemantauan secara kontinu. Pengukuran pada on line monitoring dapat dilakukan secara regular dengan selang waktu yang ditentukan atau pada saat terjadi kejadian kritis dimana parameter yang diukur jauh melebihi standard baku yang ditetapkan. Data hasil monitoring sangat berguna untuk evaluasi kegiatan atau program yang telah dan sedang berjalan, apakah ada perbaikan kondisi lingkungan atau tidak. Sebagai contoh, pada suatu aliran sungai yang sedang dilakukan program kali bersih diukur kondisi awalnya, setelah program selesai apakah ada perbaikan dapat dilihat dari hasil monitoringnya apakah ada perubahan yang cukup berarti dari program yang dilaksanakan.

\subsection{Kelembagaan}

Kelembagaan sangat menentukan dalam pengelolaan lingkungan. Dalam skala nasional lembaga yang berwenang adalah Kementrian Lingkungan Hidup, dalam skala propinsi ada Badan Pengelolaan Lingkungan Hidup (BPLHD), beberapa tempat di daerah masih memakai nama Kantor atau Dinas. Dalam dekade terakhir kelembagaan sudah jauh lebih baik dibanding dekade lalu, dan lingkungan sudah mendapat perhatian yang serius dari pemerintah dan masyarakat. Hanya saja yang perlu disoroti adalah jumlah sumberdaya manusia (SDM) yang masih dirasa kurang, padahal permasalahan lingkungan demikian banyaknya. Kekurangan SDM tersebut dapat disiasati dengan memberi peran dan ruang gerak yang lebih besar pada Lembaga Swadaya Masyarakat (LSM), agar berperan lebih aktif dalam perbaikan lingkungan. Pemerintah hanya bertindak sebagai koordinator dan motivator.

\subsection{Kelompok Sadar Lingkungan Dan Lembaga Swadaya Masyarakat}

Penanganan lingkungan perlu didukung oleh masyarakat. Pembentukan Kelompok Sadar Lingkungan (Darling) dapat dalam skala nasional maupun lokal. Namun berdasarkan pengalaman yang ada, kelompok sadar lingkungan dalam skala lokal lebih nyata hasilnya dan dapat dilihat. Kelompok Darling yang sukses akan memotivasi kelompok lain, baik yang berada di hulu dan hilirnya. Penghargaan bagi kelompok yang 
sukses juga perlu dilakukan secara konsisten oleh pemerintah sebagai langkah pembinaan.

Permasalahan lingkungan mem-punyai kecenderungan akan meningkat dari tahun ke tahun, oleh karena itu pemerintah tidak bisa berjalan sendiri dan dibutuhkan partisipasi masyarakat yang lebih kuat, dalam bentuk swadaya dan swadana masyarakat maupun investasi komersil yang difasilitasi oleh pemerintah. Kelompok Darling yang maju dapat berkembang ke arah Industri Lingkungan yang menjual produknya seperti kompos, tanaman hias atau kertas daur ulang yang mempunyai nilai komersil. Gerakan Kelompok Darling ini sebaiknya dilakukan secara nasional, dan kalau perlu dilombakan seperti Klompencapir, dengan membiasakan diri untuk memelihara lingkungan dan membisakan diri untuk hidup bersih, diharapkan lingkungan akan berkembang lebih baik dan sehat dari tahun ke tahun.

\subsection{Produksi Bersih}

Produksi bersih merupakan kegiatan internal dari pemilik usaha, namun demikian kegiatan ini juga mendapat respon yang bagus dari Pemerintah. Produksi bersih bisa dimulai dari pemilihan bahan baku, pemilihan proses yang akrab lingkungan, pengepakan, sampai dengan proses pengiriman produk. Namun demikian untuk produksi bersih diperlukan semacam standard baku mutu untuk produk tertentu, misalnya : berapa banyak jumlah limbah cair yang wajar dihasilkan untuk satu bungkus mie instanst? Dengan demikian siapapun akan dengan mudah mengetahui, apakah proses pembuatan mie tersebut akrab lingkungan atau tidak. Usaha untuk melakukan produksi bersih banyak dilakukan oleh industri-industri yang berorientasi export untuk mendapatkan ISO 14000, karena negara pengimport mempersyaratkan untuk semua produknya akrab lingkungan. Produksi bersih belum masyarakat secara baik di Indonesia, karena konsumen tidak mempunyai banyak informasi, sehingga dalam pemilihan barang produk, konsumen hanya semata-mata menilai dari kualitas dan harga yang dianggap layak.

\subsection{Teknologi Pengolahan Limbah}

Sebagai langkah pencegahan, sebaiknya setiap orang berprinsip untuk tidak membuang limbah ke perairan. Pertanyaannya adalah apakah mungkin itu terjadi ? Bagi masyarakat atau industri atau kegiatan yang terletak ditepi sungai, contohnya, akan secara sengaja atau tidak sengaja akan mengalirkan limbahnya ke sungai karena faktor topografi semata. Oleh karena itu dengan adanya sosialisasi UndangUndang dan Peraturan yang ada maka, diharapkan dengan kesadaran penuh mereka akan mengolah limbahnya sebelum dibuang ke perairan.

Teknologi Pengolahan Limbah, banyak macam dan ragamnya. Setiap jenis limbah mempunyai kekhususan dalam teknologi, tergantung jenis limbah yang akan diolah dan tingkat kesulitan dalam pengolahan. Teknologi pengolahan limbah yang ada di pasar, sebagian besar adalah merupakan paket teknologi, oleh karena itu didalam pemilihan teknologi, sebaiknya dilakukan dahulu semacam penelitian untuk mengetahui karakter limbah yang akan diolah. Dengan mengetahui karakter limbah kita akan menentukan proses pengolahan limbah yang akan dilakukan, waktu yang dibutuhkan untuk proses pengolahan, bahan dan energi yang akan digunakan, biaya konstruksi dan operasi yang akan dikeluarkan. Pengetahuan akan teknologi pengolahan limbah penting agar tidak terjadi pemborosan yang berakibat kerugian.

\subsection{Pajak Dan Bank Lingkungan}

Perbaikan, pemeliharaan, dan pembangunan lingkungan membutuhkan biaya yang tidak sedikit. Dibutuhkan suatu cara untuk mengumpulkan dana untuk pembangunan lingkungan. Selama ini, pembiayaan lingkungan tidak jelas asal-usulnya, sehingga sulit diprediksi kapan permasalahan lingkungan akan teratasi. Salah satu cara yang paling mungkin, adalah penerapan pajak lingkungan. Masalahnya bagaimana menentukan besarnya pajak lingkungan ? Dalam pajak PPN atau Pajak Pertambahan Nilai dari bahan baku menjadi barang jadi, sudah umum diketahui besarnya adalah 10\%. Padahal banyak orang juga tahu bahwa dalam memproduksi barang selalu menghasilkan limbah, baik berupa air limbah atau sampah atau pencemaran udara, ataupun hanya berupa emisi panas. Dengan demikian pajak lingkungan sebaiknya diambil dari sebagian pajak PPN yang besarnya berkisar 0,5 - 1\%. Dana tersebut dapat digunakan untuk perbaikan lingkungan dan membangun industri lingkungan.

Industri lingkungan akan sulit berkembang, jika menggunakan dana komersil yang diambil dari Bank Komersil, karena bisnis lingkungan umumnya mempunyai break event point yang lama (lebih dari 5 tahun). Oleh karena itu dibutuhkan Bank Lingkungan yang dananya dikumpulkan dari Pajak Lingkungan untuk mendanai perbaikan lingkungan dan pembangunan Industri lingkungan dengan bunga yang sangat rendah dan masa tenggang pinjam yang lama. Pembangunan Industri Lingkungan juga dapat menyerap tenaga kerja yang banyak, 
walaupun masih perlu ditunjang dengan penghargaan masyarakat yang lebih tinggi bagi mereka yang bekerja di sektor lingkungan.

\subsection{Industri Lingkungan}

Permasalahan lingkungan sering menjadi permasalahan pemerintah. Seiring dengan meningkatnya pertumbuhan penduduk dan industri, permasalahan lingkungan, baik pencemaran pada air, tanah, udara dan permasalahan sampah semakin meningkat dari hari ke hari. Akibat dari itu nampaknya pemerintah menjadi sangat sibuk mengurusi limbah dari tahun ke tahun dan kesibukan itu berakibat meningkatnya anggaran yang harus disediakan. Bersamaan dengan pembangunan dibidang ekonomi yang masih membutuhkan dana, perbaikan lingkungan sering tidak mendapat perioritas dalam pembangunan, dan bahkan cenderung pembiayaan perbaikan lingkungan didapat dari hutang atau bantuan luar negeri.

Pandangan untuk melihat limbah sebagai sumberdaya memberi angin segar untuk sejenak menatap peluang yang muncul bahwa pengolahan limbah menjanjikan keuntungan dalam berusaha. Pembangunan Industri yang bergerak di bidang lingkungan sebaiknya dilaksanakan secepat mungkin, agar Industri tersebut dapat menjadi partner pemerintah dalam mengatasi masalah lingkungan. Saat ini industri yang bergerak dibidang lingkungan masih sangat sedikit, baru ada seperti PDPAL Jaya, PT WGS, dan perusahaan-perusahaan kecil yang belum muncul namanya. Jika Industri Lingkungan terus dibina dan menjadi besar dan sehat, maka suatu saat pemerintah tidak terlalu sibuk mengurusi lingkungan, namun lebih berkonsentrasi dalam membuat kebijakan-kebijakan di bidang lingkungan.

\section{PENUTUP}

Kerusakan dan penurunan sumberdaya air terus terjadi dan semakin parah dari tahun ke tahun. Langkah-langkah untuk mengatasi permasalahan sudah banyak dilakukan, namun kerusakan tetap saja berjalan dengan kecepatan yang tidak terduga. Pencemaran air saat ini terjadi hampir diseluruh kota besar dunia dan sudah berlangsung ratusan tahun. Pengalaman negara maju ketika revolusi industri 150 tahun lalu, memberi rasa optimis bahwa masih ada kesempatan untuk Indonesia memperbaiki pencemaran yang terjadi.

Dalam penanggulangan pencemaran air, perlu dikenali terlebih dahulu sumber pencemaran, material pencemaran, sifat dan karakter bahan pencemar, kemudian kemudian dilakukan pengambilan keputusan untuk mengatasi pencemaran. Pencemaran air berpengaruh terhadap kondisi kesehatan dan lingkungan perairan. Banyak penyakit yang berhubungan dengan air yang kotor. Perlu dilakukan penggolongan atas kelas sumber air sebagai langkah pencegahan untuk perlindungan sumber air dari pencemaran dan panduan bagi penetapan baku mutu air limbah. Penetapan baku mutu air limbah harus memperhatikan kelas badan air penerima dan tidak semata-mata hanya kepada jenis industrinya.

Dalam pengendalian pencemaran perlu dilakukan perlindungan sumber air dengan cara menata tata ruang yang berwawasan lingkungan dan dilindungi oleh undang-undang yang berlaku. Monitoring dan evaluasi perlu dilakukan dalam rangka membuat sistem data yang terpadu dan kontinu, guna menunjang penegakan hukum bagi pelangaran undang-undang. Agar kordinasi kegiatan lingkungan dapat berjalan baik diperlukan kelembagaan yang mantab dan mampu memantau semua kegiatan yang berdampak lingkungan dengan dibantu oleh Lembaga Swadaya Masyarakat. Pembentukan dan pembinaan kelompok sadar lingkungan sangat diperlukan sebagai contoh nyata pengelolaan lingkungan yang baik untuk setiap wilayah atau propinsi. Perlu penguasaan teknologi pengolahan limbah untuk mengatasi pencemaran dengan biaya investasi dan operasional yang murah. Industri lingkungan juga perlu ditumbuhkan untuk meringankan beban pemerintah dalam mengatasi persoalan lingkungan, dan guna menunjang biaya investasi perlu diadakan bank lingkungan yang sumber dananya diambil dari pajak lingkungan.

\section{DAFTAR PUSTAKA}

1. Abel. P.D. 1989. Water Pollution Biology, Ellis Horwood Limited, Chichester, West Sussex, England.

2. Alaerts, G. Dan Santika, S.S. 1987. Metode Penelitian Air. Usaha Nasional. Surabaya.

3. Brault, J.L. 1991. Water Treatment Handbook. 6 th edition. Volume I dan II. Degremont. Lavoiser Publishing. Paris.

4. Djoko Pitono, 2003, Sumbangan Brantas Untuk Pembangunan Berkelanjutan, disajikan dalam Seminar Sistem Monitoring Pencemaran Lingkungan Sungai dan Teknologi Pengelolaannya, Hotel Panghegar, Bandung, 8-9 Juli 2003, Penyelenggara PPET, LIPI.

5. Gabriel Bitton. 1994. Wastewater Microbiology, A John Wiley \& Sons, INC., New York. 
6. Gordon Culp. 1984. Trihalomethane Reduction in Drinking Water. Technologies, Cost, Effectiveness, Monitoring, Compliance. Noyes Publications. New Yersey. USA. 251 Hal.

7. Lay. B.W. dan Hastowo .S. 1994. Analisis Mikroba di Laboratorium, Raja Grafindo Persada, Jakarta.

8. Manahan, S.E. 1994. Environmental Chemistry. 6 th Edition. Lewis Publishers. Boca Raton, Florida. 810 hal.

9. MetCalf dan Eddy. 2003. Waste Water Engineering, Treatment, Disposal, and Reuse. 4 th Edition, Revised by George Tchobanoglous and Franklin. L. Burton. Mc Graw Hill. New York. 1334 Hal.

10. Peraturan Pemerintah RI Nomor 16 Tahun 2005 tentang Pengembangan Sistem Penyediaan Air Minum.

11. Peraturan Pemerintah RI Nomor 51 Tahun 1993 tentang Analisis Mengenai Dampak Lingkungan.

12. Peraturan Pemerintah RI Nomor 82 Tahun 2001 tentang Pengelolaan Kualitas Air dan Pengendalian Pencemaran Air.

13. PP nomor 19 Tahun 1994 tentang Pengelolaan Limbah Bahan Berbahaya dan Beracun.

14. Saeni, N.S.1989. Kimia Lingkungan. Dep. P\&K. Ditjen Dikti. PAU ilmu Hayat IPB, Bogor.22 p.

15. Sawyer. C.N. dan McCarty. P.L. 1989. Chemistry For Environmental Engineering, International edition, McGraw-Hill Book, Singapore.

16. Surat Keputusan Tiga Menteri; Menteri Dalam Negeri, Menteri Kehutanan, Menteri Pekerjaan Umum, No. 19 tahun 1984, No. 059/Pkts-II/1984 tentang Penanganan Konservasi Tanah dalam Rangka Pengamanan Daerah Aliran Sungai Prioritas.

17. Sutopo Purwo Nugroho, 2002, Pengelolaan DAS dan Sumberdaya Air yang Berkelanjutan, Peluang dan Tantangan Pengelolaan Sumberdaya Air di Indonesia, hal 165.

18. Undang-undang Nomor 23 Tahun 1997 tentang Pengelolaan Lingkungan Hidup

19. Undang-undang Nomor 7 Tahun 2004 tentang Sumber Daya Air.

20. Viessman. W. Jr. dan Hammer. M.J. 1985. Water Supply and Pollution Control. $4^{\text {th }}$ Editon. Harper and Row Publishers. New York. 796 hal.

21. Wisnuprapto dan Mohajit. 1992. Prinsip Dasar Pengendalian Pencemaran Air. PAU. Bioteknologi ITB, Bandung.

22. Yuli. S. Slamet. 1996. Kesehatan Lingkungan. Gadjah Mada University Press. Yogyakarta. 225 hal. 